\title{
Medicine and War
}

\section{The silent Chindit mules}

\section{A J MOFFETT}

Dr Desmond Whyte's gut twisting account of the Chindit expedition published in the $B M \mathcal{F}$ last year (18-25 December 1982 , p 1776) stirred a memory. Sometime in 1942-3 I was the ear and throat specialist to No 14 British General Hospital stationed in Bareilly, Uttar Pradesh, India. I was approached by Colonel Stewart of the Indian Army Veterinary Corps. He had a problem.

A mule makes a loud braying noise that can be heard for two or three miles. The First Chindit Force-at that time a very hush hush operation-led by Colonel Orde Wingate used mules for transport. This braying of the mules alerted the enemy to the position of the force. Wingate wanted the mules silenced. Could I as a laryngologist suggest what could be done.

I said that if he could find me a couple of dead mules or a couple of mules' larynxes I would try to think up something. He agreed in principle. The difficulty seemed to be the accountability for the write off of the mules at about $£ 5$ a head and it might be a long time before one just died. So I approached Jack Shirlaw in charge of the Imperial Veterinary Research Institute at Izatnager about six miles from Bareilly. He thought that he could find me something. About two weeks later I bicycled over to Izatnager. He produced two hard and shrunken larynxes pickled in formalin. The mule has a larynx with a large laryngeal vestibule, virtually a pouch between the true vocal chord and the lateral wall of the larynx. It is covered with thin, slightly adherent mucous membrane. The chord itself is quite thin even at the lower part, where it is attached to the lateral and anterior wall of the larynx and to the arytenoid posteriorly.

"Broken wind" or "roaring" in horses is caused by an abductor paralysis of one of the vocal chords, usually the left one. Hobday's operation-the procedure used by vets to overcome broken wind-consists of exposing the interior of the larynx through the thyroid membrane-plenty of room-and stripping the mucosa from the interior of the laryngeal vestibule. This results in a large raw area. Healing by granulation and fibrosis drags the vocal chord laterally and prevents the paralysed chord falling into the airway and acting as an obstructing flutter valve, which happens in bilateral abductor paralysis in people.

My first attempt was a Hobday on one side of a larynx. It was difficult, especially in a pickled specimen, to strip the mucosa, and I abandoned it for something less troublesome. I found that it was a simple matter to seize the vocal chords between two pairs of forceps, making a shallow V, and with a pair of curved blunt nosed scissors cut round them to remove the vocal chord entire, leaving a comparatively narrow strip of raw surface across each side of the larynx. That seemed to be the answer. No vocal chords. No braying. I sent a technical memo to Colonel Stewart and was posted for temporary duty to the veterinary remount depot at Saharanpur.

Bromsgrove, Worcs

A J MOFFETT, FRCs, consulting laryngologist
Colonel Stewart met me at the station with a brake with wheels about six feet high, drawn by a pair of bay horses. I sat beside him in front. The syce hopped up behind us facing to the rear, and Colonel Stewart took the reins and drove the short distance to the cantonment. He drove very well. The cantonment was like almost every other cantonment on the plains: long low bungalows with red tiled roofs and wide shady verandas, spacious roads, some excellent trees, deep shadows, dust, cow dung, smoke, curry, and, if you looked hard enough, people everywhere.

\section{Operation day}

Next morning three mules were produced. The operating area was defined by a canvas ricksheet-about 20 feet square. On it were two large cubical canvas bales of cotton about four feet wide. One of the mules was led up by an Indian veterinary orderly and loosely hobbled. Another orderly held an intravenous drip bottle containing a solution of chloral hydrate. Colonel Stewart took a large intravenous needle between the thumb and forefinger of his right hand with the point forward, pressed his left thumb on the near side jugular vein to fill it, slapped the side of the animal's neck twice sharply with the back of his right hand, turned his hand forward, and with the third blow struck the needle into the vein. The mule never flinched. Blood flowed. Right first time. Vets are very good at this.

The needle was connected to the drip bottle. As the chloral flowed the mule's tail-the indicator of the depth of anaesthesia - went flaccid and the ears dropped, he started to totter as the hobbles were slowly tightened, an orderly gave an expert push to the shoulders, and the mule keeled over against the cotton

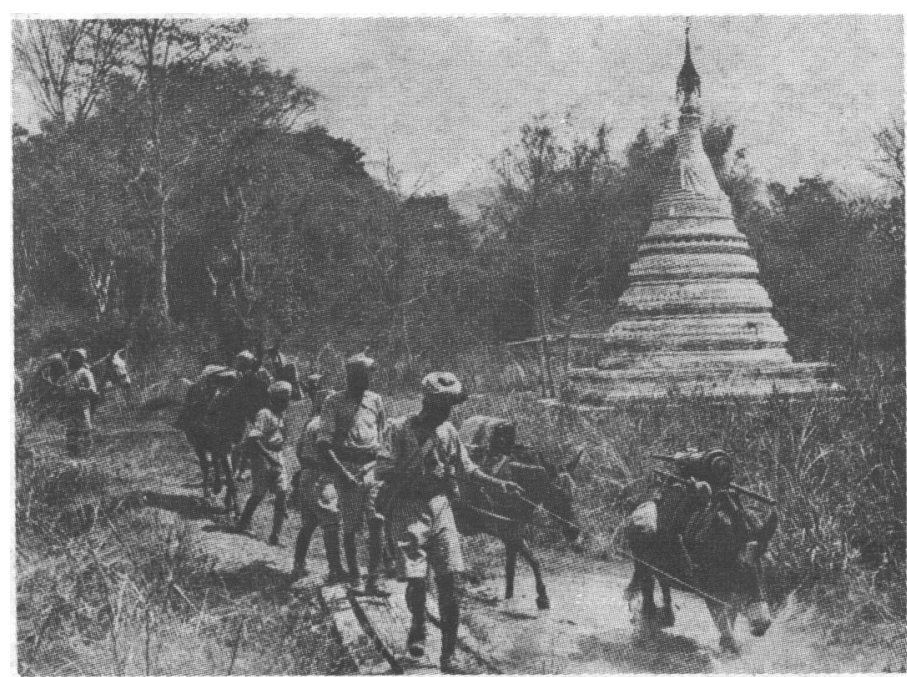

Mules working in Burma, 1942. Reproduced by kind permission of William Blackwood and Sons Ltd, Edinburgh. 
bales and sank slowly to the ground. When the hobbles were finally secured he was turned on his back, some precautions were taken to prevent him choking, and the operation began. Compared with working on a shrivelled pickled specimen the whole thing was surprisingly easy, the tissues soft and labile, and the larynx seemingly as big as a three inch drain pipe. The instruments were correspondingly large: artery forceps 12 to 15 inches long, no delicate fingers needed.

After a sop to antisepsis Colonel Stewart demonstrated the approach to the living larynx with a six inch cut down the front. He did a Hobday on one side of the larynx. I did one on the other side to access its possibility to a tyro. It did not seem very easy for either of us and meant a good deal of local trauma, which is after all the object of that particular exercise.

On the second mule I demonstrated the simple operation that I had devised, and Colonel Stewart did the other side of that larynx. Between us we did the other mule and called it a day. No complications. No sewing up. The chloral drip was removed from the vein, the hobbles taken off, and everybody stood well clear. Within minutes-encouraged by a good deal of shouting from the orderlies-the mules struggled to their feet and were led drunkenly to the horse lines. We had a drink and inspected them soon afterwards.

The Hobdayed animal was looking a bit sick. A double Hobday in one morning is a bit much even for a mule. The other two were quietly munching hay. The question of the $£ 5$ write off did not arise.

I sent a detailed technical account of the operation to Colonel Stewart and visited him a little later in Agra to go through the technical details of the operation, and had a sight of the Taj Mahal enshrouded in scaffolding. Shortly afterwards I was posted elsewhere and heard no more of the project and did not discuss it. It was still supposed to be top secret. Some time later I heard indirectly from a Chindit organiser that the operation had been put into mass production and several thousand(?) animals had been treated with a high measure of success.

I kept a draft in longhand of the memo that I had sent to Colonel Stewart. It still must be somewhere. Apart from the technical detail in my original memo this is the only written account that $I$ have made of the events leading up to the silencing of the mules.

\title{
A pilot in the first world war
}

\author{
AUSTIN BRADFORD HILL
}

In 1915 I was at Chigwell School, in the Essex village of that name immortalised by Charles Dickens in Barnaby Rudge. I was head of the school, captain of football (soccer), in the cricket $\mathrm{XI}$, champion cross country runner-and a prig. I was nearly 18 years old and intended to follow my father, Sir Leonard Hill, FRS, into medicine. He sensibly suggested that I should leave school and do my first preclinical year before being called up for war service at the age of 19 . I would, no doubt, have gone to The London, where he had been professor of physiology before joining the newly founded Medical Research Council, as director of the department of applied physiology at the Hampstead Institute. I demurred. Though the risk was probably minute, it was not unknown in those days for good natured women to carry a white feather to offer to any healthy looking chap walking around in "civvies."

I preferred to stay on at school and in the meanwhile to apply for a commission in His Majesty's service. The question was which service-the Army or the Navy? There was as yet no Air Force. The Army had its own Royal Flying Corps and the Navy its Royal Naval Air Service. What attracted me to flying I have no idea. I had seen German Zeppelins caught in London's searchlights, held like long cigars in the night sky. I saw two shot down in flames. Perhaps I saw myself fighting the monstersI was too late, for with a machine gun fitted to an aircraft and tracer bullets their day was over. Then one day a pilot in the Royal Flying Corps flew low over the cricket field to impress his brother. In this he succeeded, for he touched a tree with his wing tip and crashed. He stepped unhurt from the wreckage. It was later that I was to be warned of this occupational hazard: "Show off to your girl friend and be scraped up with a spoon."

\section{Naval interview}

The Royal Flying Corps was said to be very "choosy" and, having a deaf ear (from measles in childhood), I decided to try

April Cottage, Lower Hopton, Nesscliffe, Shropshire SY4 1DL

SIR AUSTIN BRADFORD HILL, DSC, FRS, emeritus professor of medical statistics, London School of Hygiene and Tropical Medicine my luck with the Navy. So I went for a character interview and a medical examination. The only test of hearing I recall was the "forced whisper." An attendant turned down the flap of my deaf ear, the medical officer gave a four figure number in a forced whisper. I repeated it. Now for the crunch. Fortunately (for me) their coordination had not been perfected. The medical officer made his whisper a fraction of a second before the flap of my good ear was closed. Giving a slight pause I repeated the number. There I was, undeniably fit for flying duties.

In mid-1916 I was commissioned a flight sub lieutenant, RN, and posted to HMS Crystal Palace. This was the enormous glass building in south London (burned to the ground in 1936). It had been taken over by the Navy as a "battleship" for the entry and training of recruits. It was run as a battleship: we slung our hammocks, saluted the "quarter deck," applied for "shore leave" (to go into the West End), and were given an intensive two weeks of square bashing and physical exercises. I had been a sergeant in the officers training corps at school so I was good at drill, in both performance and taking charge of a squad. I was invited to stay on and undertake the duties of training others. But I wanted to fly and was posted to HMS Chingford, one of the two Royal Naval Air Service training schools. Here, a few miles from London on the edge of Epping Forest, the aerodrome was an expanse of watery fields crisscrossed with ditches covered over by wooden slats. Opposite was the huge King George V reservoir, across which the aircraft often had to take off. In retrospect it seems an odd choice for an aerodrome.

For the first two weeks a recruit did no flying. He absorbed the atmosphere (mainly of engine oil) and performed chores. The one which stays in my mind was the manhandling of aircraft into the hangers at the end of the day. A member of my group was Ivor Novello, later of musical comedy fame. To the tune that first brought him fame, "Keep the Home Fires Burning," we sang:

Keep poor B class stowing

Though the lorry's going

Though the lorry's due to leave

The aerodrome.

There's another Maurice

Waiting out there for us,

We must shove the damned thing in

Or we can't go home. 